\title{
PENERAPAN METODE EKSPERIMEN DALAM PEMBELAJARAN SAINS UNTUK MENINGKATKAN KEMAMPUAN KOGNITIF ANAK USIA DINI
}

\author{
Ery Khaeriyah \\ IAIN Syekh Nurjati Cirebon \\ E-mail: erykhaeriyah21@syekhnurjati.ac.id
}

\author{
Aip Saripudin \\ IAIN Syekh Nurjati Cirebon \\ E-mail:aips@syekhnurjati.ac.id
}

Orcid Id: http://orcid.org/0000-0003-1815-9274

Riri Kartiyawati

Roudhatul Athfal Islamiyah Indramayu

E-mail: shopfun16@gmail.com

Article received: 29 Agustus 2018, Review process: 31 Agustus 2018

Article published: 30 September 2018

\begin{abstract}
The application of science for early childhood emphasizes giving experience directly to children. Children are required to be able to experiment independently. Stages Learning science in early childhood is still in the form of color recognition, color mixing, plant recognition, animal recognition, and recognizing natural symptoms in the environment. This study uses classroom action research conducted collaboratively using the Kemmis and Mc Taggart research models. Subjects in this study were 14 children, consisting of 4 men and 10 women. The purpose of this study was to improve early childhood cognitive abilities through experimental methods in science learning. Data collection techniques used are observation and documentation. While the data analysis technique uses qualitative and quantitative descriptive analysis techniques. The results of the action research can be seen from the observation of the development of children in each cycle, namely in the pre cycle to get a score of $44.38 \%$, in the first cycle was $61.21 \%$, and in the second cycle was $78.86 \%$. The increase in cycle I to cycle II was $17.65 \%$, so the percentage of the application of experimental methods in science learning to improve cognitive abilities of early childhood reached a success indicator of $75 \%$. In other words, the use of experimental methods in professional learning can improve cognitive abilities in early childhood. Seen from the results of the cycle which achieved more than $75 \%$ success.
\end{abstract}

Keywords: experimental methods, science learning, cognitive abilities, early childhood

Abstrak
Penerapan sains untuk anak usia dini menekankan pada pemberian pengalaman secara langsung kepada
anak. Anak dituntut untuk mampu melakukan eksperimen secara mandiri. Tahapan Pembelajaran sains
$\begin{aligned} & \text { Penerapan Metode Eksperimen dalam } \\ & \text { Pembelajaran Sains untuk Meningkatkan } \\ & \text { Kemampuan Kognitif Anak Usia Dini }\end{aligned}$


pada anak usia dini masih berupa pengenalan warna, pencampuran warna, pengenalan tumbuhan, pengenalan binatang, serta mengenal gejala-gejala alam di lingkungannya. Penelitian ini menggunakan penelitian tindakan kelas yang dilakukan secara kolaboratif dengan menggunakan model penelitian Kemmis dan Mc Taggart. Subjek dalam penelitian ini sebanyak 14 anak, yang terdiri dari 4 laki-laki dan 10 perempuan. Tujuan penelitian ini adalah untuk meningkatkan kemampuan kognitif anak usia dini melalui metode experimen dalam pembelajaran sains. Teknik pengumpulan data yang digunakan adalah observasi dan dokumentasi. Sedangkan teknik analisis data menggunakan teknik analisis deskriptif kualitatif dan kuantitatif. Hasil penelitian tindakan dapat diketahui dari pengamatan perkembangan anak pada setiap siklusnya yaitu pada pra siklus memperoleh skor sebesar 44,38\%, pada siklus I sebesar $61,21 \%$, dan pada siklus II sebesar 78,86\%. Peningkatan siklus I ke siklus II sebesar $17,65 \%$, sehingga presentase penerapan metode eksperimen dalam pembelajaran sains untuk meningkatkan kemampuan kognitif anak usia dini mencapai indikator keberhasilan yaitu 75\%. Dengan kata lain bahwa penggunaan metode eksperimen dalam pembelajaran saisn dapat meningkatkan kemampuan kognitif pada anak usia dini. Terlihat dari hasil siklus yang mencapai keberhasilan lebih dari $75 \%$.

Kata kunci: metode eksprimen, pembelajaran sains, kemampuan kognitif, Anak usia dini

\section{PENDAHULUAN}

Pendidikan Anak usia Dini (PAUD) sebagaimana yang dinyatakan dalam UndangUndang Nomor 20 Tahun 2003 tentang Sistem Pendidikan Nasional (pasal 1 ayat 14) adalah upaya pembinaan yang ditujukan kepada anak sejak lahir sampai dengan usia enam tahun yang dilakukan melalui pemberian rangsangan pendidikan untuk pertumbuhan dan perkembangan jasmani dan rohani agar anak memiliki kesiapandalam memasuki pendidikan lebih lanjut. Hakikatnya pendidikan merupakan belajar yang berlangsung sepanjang hayat. Oleh karena itu, pendidikan harus dilakukan sejak dini melalui program pendidikan anak usia dini (PAUD) sampai lanjut usia (lansia). Untuk mewujudkannya maka dipersiapkan pola pendidikan, pengasuhan dan pengembangan anak usia dini secara terencana, terpadu dan menyeluruh yang melibatkan semua komponen yang dapat mempengaruhi tumbuh dan berkembangnya anak usia dini (Saripudin. 2017: 1). Secara spesifik PAUD yaitu rentang usia 0-6 tahun menjadi fenomena sangat penting sejak dipublikasikannya hasil-hasil riset di bidang psikologi, mendeskripsikan bahwa potensi kecerdasan dan dasar-dasar perilaku seseorang terbentuk pada rentang usia dini dan masa ini sering disebut usia emas.

Pendidikan Anak Usia Dini (PAUD) adalah pendidikan yang diselenggarakan dengan tujuan untuk memfasilitasi pertumbuhan dan perkembangan anak secara menyeluruh atau

$\begin{array}{lrr}\text { Penerapan } & \text { Metode } & \text { Eksperimen dalam } \\ \text { Pembelajaran Sains untuk Meningkatkan } & \text { Ery Khaeriyah, Aip Saripudin, } \\ \text { Kemampuan Kognitif Anak Usia Dini } & \text { Riri KKartiyawati }\end{array}$


menekankan pada pengembangan seluruh aspek kepribadian anak. Oleh karena itu, PAUD memberikan kesempatan bagi anak untuk mengembangkan kepribadian dan potensi secara maksimal. Atas dasar ini, lembaga PAUD perlu menyediakan berbagai kegiatan ketika belajar dalam kelas yang dapat mengembangkan berbagai aspek perkembangan seperti kognitif, bahasa, sosial, emosi, fisik, dan motorik (Suyadi, 2014:22-23).

Pembelajaran sains pada anak usia dini masih berupa pengenalan warna, pencampuran warna, tumbuhan, binatang, gejala alam dan lain-lain. Anak-anak harus diajarkan bagaimana merasakan, mengalami, dan mencoba berbagai fenomena alam. Seperti kegiatan yang berhubungan dengan eksperimen ini yaitu ekspeimen pengenalan dan pencampuran warna, gunung meletus atau gejala alamlainnya. Eksperimen ini akan memacu kreativitas anak, belajar untuk berani mencoba suatu sifat yang ini sangat berharga dan langka di dunia orang dewasa. Sains dapat mengajak anak untuk berpikir kritis, karena dengan sains anaktidak begitu saja menerima atau menolak sesuatu. Mereka mengamati, menganalisis dan mengevaluasi informasi yang ada, dengan melakukan percobaan-percobaan sains dan keterampilan proses anak-anak dapat ditingkatkan kemampuan sainsnya.

Pembelajaran sains menekankan pada pemberian pengalaman secara langsung. Dengan demikian, anak perlu dibantu untuk mengembangkan sejumlah ketrampilan proses sains agar mampu menjelajahi serta memahami alam sekitarnya. Dengan memberikan pembelajaran sains sejak usia dini dapat melatih anak dalam menggunakan pikirannya, kekuatannya, kejujurannya serta teknik-teknik yang dimilikinya dengan penuh kepercayaan diri, sehingga tugas guru adalah mengembangkan program pembelajaran sains yang dapat mengeksplorasi dan berorientasi sains secara optimal (Nugraha, 2008: 24). Berdasarkan hasil observasi awal yang dilakukan oleh peneliti di kelas B pada bulan Agustus-Oktober 2016 ditemukan adanya keterlambatan dalam kemampuan kognitif dan pengetahuan sains sebesar 78\% dari 14 anak yang hasil belajarnya belum memenuhi kriteria. Sehingga yang sudah berhasil dengan kriteria baik hanya sekitar $28 \%$.

\section{KAJIAN TEORITIK}

\section{Metode Pembelajaran Eksperimen}

Secara bahasa, metode adalah cara yang ditempuh. Menurut Sulchan, (1997:335) metode berarti cara yang disusun dan teratur untuk mencapai tujuan khususnya dalam hal ilmu

$\begin{array}{lrr}\text { Penerapan Metode Eksperimen dalam } & \text { Ery Khaeriyah, Aip Saripudin, } \\ \text { Pembelajaran Sains untuk Meningkatkan } & \text { Riri KKartiyawati } \\ \text { Kemampuan Kognitif Anak Usia Dini } & \end{array}$


pengetahuan. Yang mengatakan bahwa metode adalah cara-cara yang dapat digunakan oleh peneliti. Menurut Behaviorisme, pembelajaran adalah upaya pendidik untuk membantu anak didik melakukan kegiatan belajar sehingga menghasilkan perubahan perilaku pada anak didik. Pembelajaran secara umum, dapat diartikan suatu proses perubahan, yaitu perubahan dalam perilaku sebagai hasil interaksi antara dirinya dengan lingkungannya. Secara lengkap pengertian pembelajaran adalah "suatu proses yang dilakukan oleh individu untuk memperoleh suatu perubahan perilaku yang baru secara keseluruhan, sebagai hasil dari pengalaman individu itu sendiri dalam interaksi dengan lingkungannya. Dari definisi tersebut, dapat dikatakan bahwa pembelajaran merupakan proses interaksi anak usia dini dengn guru dan sumber belajar pada suatu lingkungan belajar untuk membantu membimbing anak belajar dengan baik sesuai dengan tahap perkembangannya sehingga menghasilkan perubahan tingkah laku menjadi lebih baik. (Saifuddin, 2014:3).

Terdapat dua hal yang berbeda antara strategi dengan metode. Strategi pembelajaran merupakan salah satu jurus untuk melakukan proses pembelajaran agar tujuan pembelajaran bisa tercapai dan materi pembelajaran bisa tersampaikan dengan baik. Sedangkan metode pembelajaran yang diterapkan guru di kelas menjadi faktor penyebab lainnya, terkadang guru menerapkan metode yang kurang sesuai dengan kondisi sekolah dan anak didik sehingga mengakibatkan kejenuhan di dalam pembelajaran (Saripudin \& Fauziah, 2018: 130). Lebih lanjut Metode pembelajaran adalah suatu cara merupakan satu kata yang merujuk pada cara yang akan digunakan untuk mencapai sebuah tujuan yang diharapkan. Dan jika dikaitkan dengan proses pembelajaran, maka definisi metode pembelajaran dapat diartikan sebagai suatu cara yang dipilih oleh pendidik untuk mengoptimalkan proses belajar mengajar yang bertujuan untuk mencapai tujuan pembelajaran yang diharapkan. Metode yang menggunakan pembelajaran memberikan kesempatan dan kebebasan pada anak untuk mengemukakan pemikirannya, mereka mengemukakan pemikirannya sendiri dan dan mengidentifikasi kegiatannya. Metode pembelajaran juga segala usaha guru untuk mengumpulkan data, untuk menerapkan berbagai metode pembelajaran dalam mencapai tujuan yang diharapkan. Dengan demikian, metode pembelajaran menekankan kepada berbagai aktivitas guru mengajar dan keaktivitasan anak belajar (Mursid, 2015:37).

$\begin{array}{lrr}\text { Penerapan Metode } & \text { Eksperimen dalam } & \text { Ery Khaeriyah, Aip Saripudin, } \\ \text { Pembelajaran Sains untuk Meningkatkan } & \text { Riri KKartiyawati } \\ \text { Kemampuan Kognitif Anak Usia Dini }\end{array}$


Berikut ini merupakan metode-metode pembelajaran yang sesuai dengan karakteristik anak usia dini: bermain, karyawisata, bercakap-cakap, bercerita, demonstrasi atau eksperimen, proyek, pemberian tugas (Moeslichatoen, 2004: 24). Metode-metode tersebut sesuai dengan aspek perkembangan anak usia dini sebagaimana yang tercantum pada Permen Diknas No. 137 Tahun 2014, yaitu tentang: Nilai Agama dan Moral, Bahasa, Kognitif, Fisik-Motorik dan Sosisl Emosional (Mukhtar Latif, 2013:108). Diantara metode-metode pembelajaran tersebut, menurut Schoenherr (1996) metode eksperimen adalah metode yang paling cocok untuk diterapkan kepada anak usia dini pada pempelajaran sains dalam meningkatkan kemampuan kognitifnya.

Metode eksperimen merupakan cara penyajian bahan pelajaran dimana siswa melakukan percobaan dengan mengalami untuk membuktikan sendiri sesuatu pertanyaan atau hipotesis yang dipelajari. Metode eksperimen adalah suatu cara mengajar, di mana siswa melakukan suatu percobaan tentang sesuatu hal, mengamati prosesnya serta menuliskan hasil percobaannya, kemudian hasil pengamatan itu disampaikan ke kelas dan dievaluasi oleh guru, eksperimen merupakan keterampilan yang banyak dihubungkan dengan sains (ilmu pengetahuan). Eksperimen atau percobaan dapat dikatakan sebagai suatu proses yang harus dikuasai anak sebagai suatu cara untuk memahami konsep tentang sesuatu hal ataupun penguasaan anak tentang konsep dasar eksperimen, melainkan bagaimana mereka dapat mengetahui cara atau proses terjadinya sesuatu dan mengapa sesuatu dapat terjadi serta bagaimana mereka dapat menemukan solusi terhadap permasalahan yang ada dan pada akhirnya mereka dapat membuat sesuatu yang bermanfaat dan kegiatan tersebut (Yeni, 2010:58).

Menurut Schoenherr (1996) dalam Palendeng (2003:81) metode eksperimen adalah metode yang sesuai untuk pembelajaran sains, karena metode eksprimen mampu memberikan kondisi belajar yang dapat mengembangkan kemampuan berfikir dan kreativitas secara optimal. Siswa diberi kesempatan untuk menyusun sendiri konsep-konsep dalam struktur kognitifnya, selanjutnya dapat diaplikasikan dalam kehidupannya.

\section{Konsep Dasar Sains Anak Usia Dini}

Sains adalah pembelajaran yang mempelajari pengetahuan alam yang dilakukan dengan pengamatan. Sains merupakan cara kita berpikir dan melihat dunia sekitar kita yang menyajikan fakta-fakta atau kenyataan yang terkait dengan fenomena alam, (Desmita 2007:29). Menurut

$\begin{array}{lrr}\text { Penerapan Metode Eksperimen dalam } & \text { Ery Khaeriyah, Aip Saripudin, } \\ \text { Pembelajaran Sains untuk Meningkatkan } & \text { Riri KKartiyawati } \\ \text { Kemampuan Kognitif Anak Usia Dini }\end{array}$


Nugraha (2008:3), mendefinisikan sains sebagai bidang ilmu alamiah, dengan ruang lingkup zat dan energi, baik yang terdapat pada benda hidup maupun pada benda mati, yang lebih banyak membahas tentang alam (natural science) seperti fisika, kimia dan biologi. Kaitannya dengan program-program pembelajaran sains usia dini, sains dapat dikembangkan menjadi tiga substansi mendasar, yaitu pendidikan dan pembelajaran sains yang menfasilitasi penguasaan proses sains, penguasaan produk sains serta program yang menfasilitasi pengembangan sikap-sikap sains.

Dalam hal ini dapat kita pahami bahwa sains ternyata bukan hanya berisi rumus-rumus atau teori, melainkan juga mengandung nilai-nilai manusiawi yang bersifat universal dan layak dikembangkan serta dimiliki oleh setiap individu di dunia ini, bahkan dengan begitu tingginya nilai sains bagi kehidupan, menyebabkan pembekalan sains seharusnya dapat diberikan sejak usia anak masih dini. Menurut Amein, (2008:3) bahwa sains merupakan pengetahuan tentang fenomena-fenomena tertentu, proses yang digunakan untuk mengumpul dan mengevaluasi informasi, dan sebagai bentuk adaptasi manusia pada lingkungan.

Sehingga dapat disimpulkan bahwa sains merupakan semua yang ada disekitar kita, terjadidimana kita berada. Sains pada anak usia dini dapat diartikan sebagaihal-hal yang menstimulus mereka untuk meningkatkan rasa ingin tahu, minat dan pemecahan masalah, sehingga memunculkan pemikiran dan perbuatan seperti mengobservasi, berpikir, dan mengaitkan antar konsep atau peristiwa. Maka dapat disimpulkan bahwa kemampuan sains anak usia dini adalah kegiatan pada anak usia dini, diantaranya: kemampuan mengamati, mengklasifikasi, menarik kesimpulan, mengkomunikasikannya berdasarkan pengalaman sains yang diperolehnya. Pembelajaran sains menyatakan bahwa tujuan pendidikan sains sejalan dengan kurikulum sekolah, yakni mengembangkan anak secara utuh baik aspek dominan kognitif, aspek afektif maupu aspek psikomotor anak usia dini (Crain 2007:47). Sementara tujuan sains yang mendasar adalah untuk memupuk pemahaman, minat dan penghargaan anak didik terhadap dunia dimana dia hidup, (Sumaji 2001:72). Fokus dan tekanan pendidikan sains terletak pada bagaimana kita membiarkan diri anak dididik oleh alam agar menjadi lebih baik, makna di didik dengan alam melatih anak untuk jujur dan tidak berprasangka, (Indrawati 2001:23).

Nugraha (2008:55) mengemukakan bahwa tujuan pembelajaran sains bagi anak usia dini diantaranya yaitu (1) agar anak-anak memiliki kemampuan memecahkan masalah yang

$\begin{array}{lrr}\text { Penerapan Metode Eksperimen dalam } & \text { Ery Khaeriyah, Aip Saripudin, } \\ \text { Pembelajaran Sains untuk Meningkatkan } & \text { Riri KKartiyawati } \\ \text { Kemampuan Kognitif Anak Usia Dini }\end{array}$


dihadapinya melalui penggunaan metode sains, (2) agar anak memiliki sikap-sikap ilmiah, (3) agar anak mendapatkan pengetahuan dan informasi ilmiah, (4)agar anak-anak menjadi lebih berminat dan tertarik untuk menghayati sains yang berada dilingkungan.

Berdasarkan tujuan tersebut jelaslah bahwa pengembangan pembelajaran sains bukan saja membina kognitif (misal melalui observasi, membaca, diskusi, eksperimen) anak saja, melainkan membina aspek afektif dan psikomotor (motorik kasar dan motorik halus). Selain itu, bukan saja menunggu proses kematangan secara alamiah, namun juga perlu rangsangan dari lingkungan keluarga sehingga, anak berkembangan dengan baik (Saripudin, 2016).

\section{Konsep Perkembangan Kognitif}

Kognitif secara bahasa adalah cognitive berasal dari kata cognition yang pandangannya knowing, berarti mengetahui. Dalam arti luas, cognition (kognisi) ialah perolehan, penataan, dan penggunaan pengetahuan. Dalam perkembangan selanjutnya, istilah kognitif menjadi populer sebagai salah satu domain atau wilayah/ ranah dalam taksonomi pendidikan (Muhibbin, 2012. 22). Secara umum kognitif diartikan potensi intelektual yang terdiri dari tahapan diantaranya yaitu: pengetahuan (knowledge), pemahaman (comprehention), penerapan (application), analisa (analysis), sintesa (sinthesis), evaluasi (evaluation). Kognitif adalah kemampuan untuk mengembangkan kemampuan rasional (akal). Teori kognitif sendiri lebih menekankan bagaimana proses atau upaya untuk mengoptimalkan kemampuan aspek rasional yang dimiliki oleh orang lain. Oleh sebab itu kognitif berada dengan teori behavioristik yang lebih menekankan pada aspek kemampuan perilaku yang diwujudkan dengan cara kemampuan merespons terhadap stimulus yang datang kepada dirinya (Retno, Pusdiklat KNPK).

Kemampuan kognitif menurut Jean Piaget yang dimiliki anak usia 5-6 tahun yaitu sudah dapat memahami jumlah dan ukuran, tertarik artikel baru huruf dan angka, ada yang sudah mampu menulis atau menyalinnya serta menghitungnya, sudah mengenal sebagian besar warna, mengenal bentuk, mulai mengerti tentang waktu, kapan harus pergi ke sekolah dan pulang sekolah, mengenal nama-nama hari dalam satu minggu dan pada usia akhir enam tahun anak sudah mampu membaca, menulis dan berhitung. Dalam mengembangkan kemampuan kognitif anak diperlukan proses pembelajaran yang efektif, menyenangkan, menarik dan bermakna bagi anak. Proses pembelajaran tersebut dipengaruhi oleh berbagai unsur, antara lain guru yang

$\begin{array}{lrr}\text { Penerapan Metode } \quad \text { Eksperimen dalam } & \text { Ery Khaeriyah, Aip Saripudin, } \\ \text { Pembelajaran Sains untuk Meningkatkan } & \text { Riri KKartiyawati } \\ \text { Kemampuan Kognitif Anak Usia Dini }\end{array}$


memahami secara utuh hakikat, sifat karakteristik anak, metode pembelajaran yang berpusat pada kegiatan anak, sarana kegiatan anak yang memadai, ketersediaannya berbagai sumber dan media belajar yang menarik dan mendorong anak untuk belajar.

Kognitif dapat berarti kecerdasan, berpikir, dan mengamati, yaitu tingkah laku yang mengakibatkan orang memperoleh pengetahuan yang diperlukan untuk menggunakan pengetahuan. Dengan pengertian ini, maka perkembangan kognitif adalah anak yang mampu mengordinasikan berbagai cara berpikir untuk menyelesaikan persoalan-persoalan dengan merancang, mengingat, dan mencari alternatif bentuk penyelesaian persoalan, merupakan tolak ukur perkembangan kognitif. (Eti Nurhayati, 2011: 16). Menurut teori fundamental Piaget seorang ahli psikologi kognitif, adalah ide bahwa perkembangan anak-anak melalui beberapa tahap dan pengalaman interpretasi dunia akan tergantung ditahap mana mereka berada. Dengan demikian, kita melihat apa yang terjadi dalam tahap pertama Piaget, yaitu tahap sensorimotor pada bayi.

Tahap Sensorimotor (0-2 Tahun), tahap ini berlangsung sejak kelahiran sampai sekitar usia dua tahun. Dalam tahap ini bayi menyusun pemahaman dunia dengan mengordinasikan pengalaman indranya (sensori) seperti melihat, mendengar dengan gerakan motor (otot) - nya untuk menggapai, menyentuh dan oleh karenanya disebut sebagai sensorimotor.

Tahap Praoperasional (2- 7 Tahun), tahap praoperasional terentang dari kira-kira usia 2 hingga 7 tahun. Pada tahap inilah konsep yang stabil dibentuk, penalaran mental muncul, egosentrisme, mulai kuat dan kemudian lemah, serta keyakinan terhadap hal yang magis terbentuk. Pemikiran praoperasional tidak lain dari masa tunggu yang longgar bagi pemikiran operasional konkret.

Tahap operasional konkret (7-11 Tahun), pemikiran operasional konkret mencakup penggunaan operasi. Penalaran logika menggantikan penalaran intuitif, tetapi hanya dalam situasi konkret. Kemampuan untuk menggolong-golongkan sudah ada, tetapi belum bisa memecahkan problem-problem abstrak. Kemampuan tahap operasi konkret yang juga penting adalah mengklasifikasikan atau membagi menjadi sub yang berbeda-beda dan memahami hubungannya. Seperti pemahaman pohon keluarga yang terdiri dari empat generasi mengungkapkan kemampuan operasional konkret anak.

\begin{tabular}{|c|c|}
\hline $\begin{array}{l}\text { Penerapan Metode Eksperimen dalam } \\
\text { Pembelajaran Sains untuk Meningkatkan } \\
\text { Kemampuan Koanitif Anak Usia Dini }\end{array}$ & $\begin{array}{r}\text { Ery Khaeriyah, Aip Saripudin, } \\
\text { Riri KKartiyawati }\end{array}$ \\
\hline
\end{tabular}


Tahap operasional formal Remaja (11-15 Tahun), pemikiran operasional formal lebih abstrak dari pada seorang anak. Remaja tidak lagi terbatas pada pengalaman konkret aktual sebagai dasar pemikiraan sebaliknya mereka dapat memunculkan khayalan, kemungkinan hipotetis atau dalil-dalil dan pemalaran yang abstrak.

Pengetahuan adalah kemampuan menyebutkan atau menjelaskan kembali. Contoh: menyatakan kebijakan. Pemahaman adalah kemampuan memahami instruksi/masalah, menginterpretasikan dan menyatakan kembali dengan kata-kata sendiri. Contoh : Menuliskan kembali atau merangkum materi pelajaran. Aplikasi adalah kemampuan menggunakan konsep dalam praktek atau situasi yang baru. Contoh: Menggunakan pedoman/ aturan dalam menghitung gaji pegawai. Analisa adalah kemampuan memisahkan konsep kedalam beberapa komponen untuk memperoleh pemahaman yang lebih luas atas dampak komponen - komponen terhadap konsep tersebut secara utuh. Contoh: Menganalisa penyebab meningkatnya harga pokok penjualan dalam laporan keuangan dengan memisahkan komponen- komponennya. Sintesis adalah kemampuan merangkai atau menyusun kembali komponen-komponendalam rangkamenciptakan arti/pemahaman/struktur baru. Contoh: Menyusun kurikulum dengan mengintegrasikan pendapat dan materi dari beberapa sumber. Evaluasi adalah kemampuan mengevaluasi dan menilai sesuatu berdasarkan norma, acuan atau kriteria. Contoh: Membandingkan hasil ujian siswa dengan kunci jawaban.

\section{METODOLOGI}

Penelitian ini menggunakan Penelitian Tindakan Kelas (PTK), yaitu suatu penelitian yang dilakukan secara sistematis reflektif terhadap berbagai "aksi" atau tindakan oleh guru/pelaku, mulai dari perencanaansampai dengan penelitian terhadap tindakan nyata di dalam kelas yang berupa kegiatan belajar mengajar untuk memperbaiki kondisi pembelajaran yang dilakukan. Prosedur atau langkah-langkah penelitian yang dilakukan terbagi dalam bentuk siklus kegiatan mengacu pada model yang diadopsi dari Hopkins (1993:48), dimana setiap siklus terdiri atas empat kegiatan pokok adalah kegiatan: perencanaan tindakan, pelaksanaan, observasi dan refleksi. Berikut adalah penjelasan langkah-langkah penelitian diatas:

\section{Penerapan Metode Eksperimen dalam Pembelajaran Sains untuk Meningkatkan Kemampuan Kognitif Anak Usia Dini}

Ery Khaeriyah, Aip Saripudin,

Riri KKartiyawati 
Perencanaan (Planning), dalam perencanaan ini peneliti membuat RPPH, menyiapkan media yang akan digunakan untuk melakukan percobaan sederhana (pencampuran warna) dengan berkolaboratif bersama guru kelas. Sedangkan pelaksanaan peneliti menyiapkan bahan-bahan eksperimen, menjelaskan bagaimana pembelajarannya. Observasi mengamati proses pembelajaran, mengamati siswa yang sedang bermain eksperimen dan mendokumentasikan proses pembelajarannya. Selanjutnya refleksi, dalam tahap refleksi peneliti melakukan analisis data yang telah di dapatkan dengan melakukan kategorisasi dan penyimpulan data yang telah didapat dalam tahap pengamatan. Adapun subjek dalam penelitian ini adalah anak-anak usia 5-6 tahun atau kelompok B semester II di RA Baiturrahman tahun ajaran 2017/2018 dengan jumlah siswa 17 anak, yang terdiri dari 10 anak laki-laki, dan7 anak perempuan. Dalam subjek partisipasi dalam PTK ini adalah peneliti sendiri (sekaligus berperan sebagai guru sentral) dan dibantu oleh dewan guru di RA Baiturrahman.

Adapun indikator pencapaian perkembangan kognitif dan pengetahuan sains pada anak usia 5-6 tahun menurut Standar Nasional Pendidikan Anak Usia Dini Permendiknas Nomor 146 Tahun 2014 yaitu kemampuan kognitif dalam pembelajaran sains, (konsentrasi) mengklasifikasikan benda berdasarkan warna, bentuk,dan ukuran, (kreatif) Menunjukkan sikap kreatif dalam menyelesaikan masalah, (pemahaman) mengenal lingkungan alam, (kelancaran) Mengetahui dan mampu cara memecahkan masalah sehari-hari dan berperilaku kreatif.

Penelitian menggunakan dua metode pengumpulan data yakni observasi dan dokumentasi. Adapun teknik analisis data pada penelitian tindakan kelas merupakan bukti adanya peningkatan atau perbaikan dari sebuah proses pembelajaran. Hasil yang diperoleh, didapat dari data selama observasi penelitian. Analisis data yang dipakai adalah teknik analisis data deskriptif kualitatif dan kuantitatif. Deskriptif kualitatif merupakan menganalisa data denga cara menjelaskan dan menggambarkan hasil penelitian dengan kata-kata atau kalimat, sementara deskriptif kuantitatif merupakan data yang diperoleh berupa angka-angka untuk mengetahui persentase kemampuan kognitif dalam pembelajaran sains anak.

\section{Penerapan Metode Eksperimen dalam Pembelajaran Sains untuk Meningkatkan Kemampuan Kognitif Anak Usia Dini}

Ery Khaeriyah, Aip Saripudin,

Riri KKartiyawati 
Ketuntasan individu dan klasikal dengan rumus sebagai berikut:

$$
\begin{array}{|l|l|}
\hline \mathrm{S}=\frac{\mathrm{R}}{\mathrm{N}} \times 100 \% & \\
& \mathrm{~S}=\text { Persentase Ketuntasan Individual } \\
& \mathrm{R}=\text { Skor Yang diperoleh } \\
& \mathrm{N}=\text { Skor Maksimal }
\end{array}
$$

\begin{tabular}{|c|c|}
\hline $\mathrm{PK}=\frac{\mathrm{IT}_{\mathrm{T}}}{\mathrm{IS}} \mathrm{X} 100 \%$ & $\begin{array}{l}\text { Keterangan: } \\
\text { PK = Persentase Ketuntasan Klasikal } \\
\text { JT = Jumlah Anak yang Tuntas } \\
\text { JS = Jumlah Seluruh Anak }\end{array}$ \\
\hline
\end{tabular}

Anak dikatakan tuntas secara individual apabila anak tersebut mencapai nilai 75\% (Mulyasa: 2012, 183).

Ketuntasan Belajar Klasikal dengan rumus

Anak dikatakan tuntas secara klasikal apabila siswa tersebut mencapai nilai 75\% (Mulyasa: 2012, 183).

Menurut Mulyasa (2012:183), tingkat keberhasilan yang diharapkan terjadi minimal 75\% dengan kriteria tiap sekor.Hasil analisis ini menggunakannya itu yang dijadikan sebagai bahan refleksi untuk mendapatkan penilaian dengan cara yang lebih sesuai dalam program belajar mengajar yang di inginkan (mulyasa, 2012: 183).

\section{HASIL DAN PEMBAHASAN}

Penelitian yang dilakukan merupakan penelitian tindakan kelas (PTK) yang terdiri dari dua siklus dengan lima kali pertemuan dalam setiap siklusnya. Langkah-langkah setiap siklus yaitu perencanaan, pelaksanaan, observasi dan refleksi. Hasil penelitian ini dari pra siklus, siklus I, suklis II.

Hasil penelitian pada pra siklus mengenai kemampuan kognitif pada pembelajaran sains anak, dapat dilihat dalam diagram dibawah ini:

\section{Penerapan Metode Eksperimen dalam Pembelajaran Sains untuk Meningkatkan Kemampuan Kognitif Anak Usia Dini}

Ery Khaeriyah, Aip Saripudin,

Riri KKartiyawati 


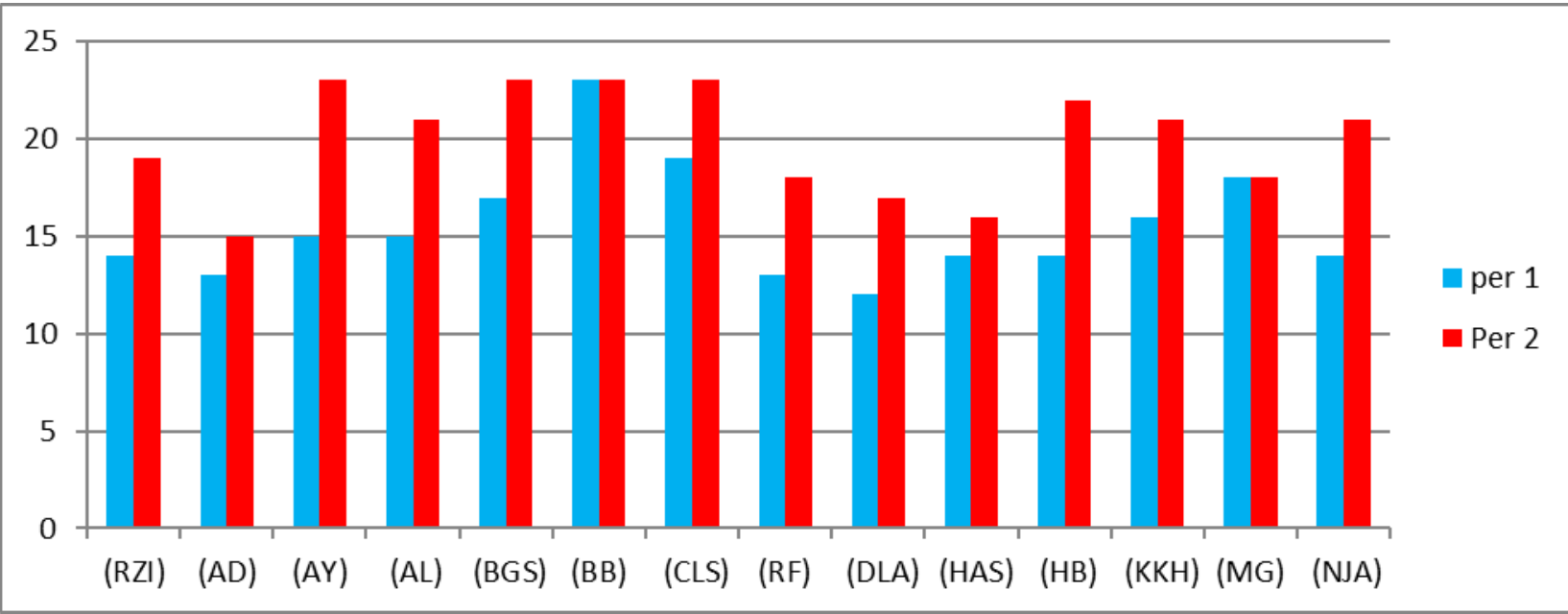

Gambar 1: Diagram Hasil Pengamatan Pra Siklus

Pada kegiatan pra siklus, yakni kegiatan pembelajaran sebelum menggunakan metode eksperimen, maka dapat dikatakan kemampuan kognitif anak dalam penguasaan saisn masih rendah. Terbukti pada pra siklus yang dilaksanakan selama dua kali pertemuan menunjukan prosentase sebesar 78\% anak yang belum mampu dalam pembelajaran saisn dengan indikator kognitif. Hal ini membuat penelitia semakin yakin akan penggunaan metode eksperimen dalam kegiatan pembelajaran.

Pada Siklus pertama yang dilakukan selama lima kali pertemuan, maka rata-rata keberhasilan yang dicapai anak dalam kemampuan kognitif pada pembelajaran sains sebesar $61,21 \%$. Untuk lebih jelasnya, maka dapat dilihat pada grafik dibawah ini: 


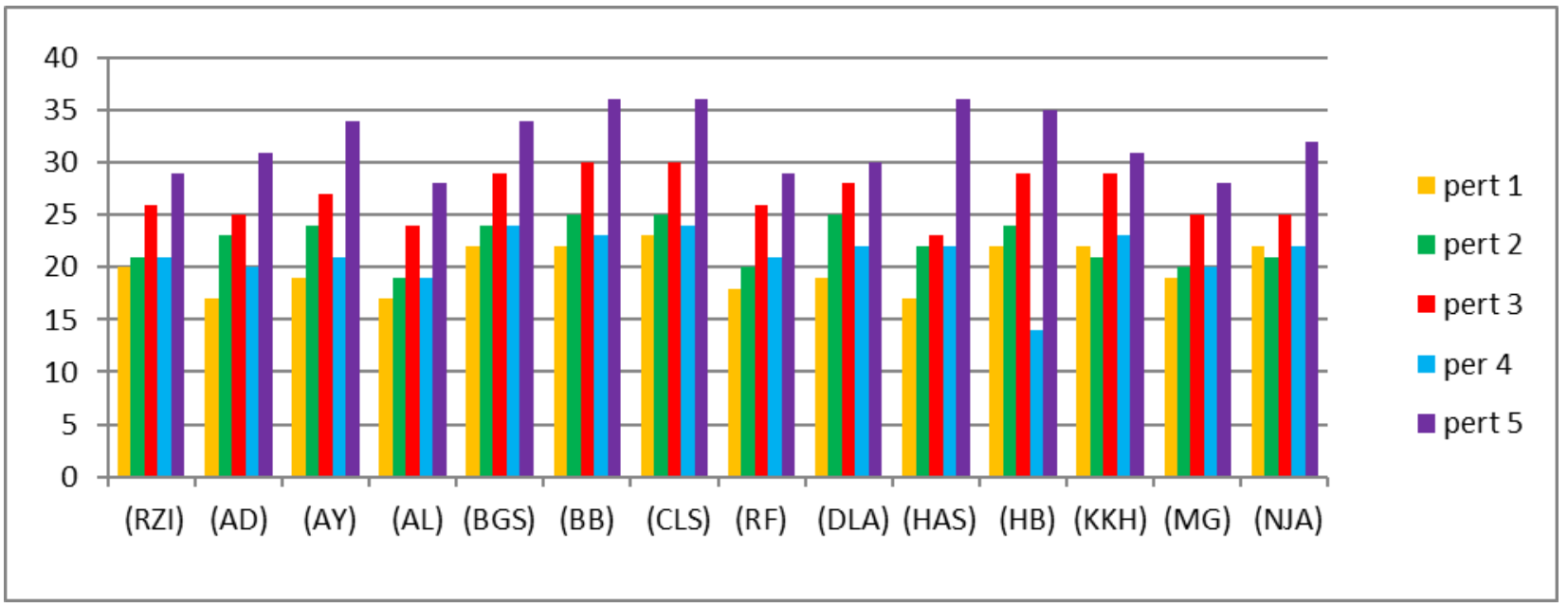

Gambar 2. Diagram Hasil Pengamatan Siklus Pertama

Pada Siklus kedua yang dilakukan selama lima kali pertemuan, maka rata-rata keberhasilan yang dicapai anak sebesar 78,86\%. Nilai ini sesuai dengan teori yang menyatakan bahwa, anak dikatakan berhasil jika nilai lebih besar dari 75\%. Untuk melihat hasil pengamatan pada siklus kedua dapat dilihat dalam diagram batang berikut ini:

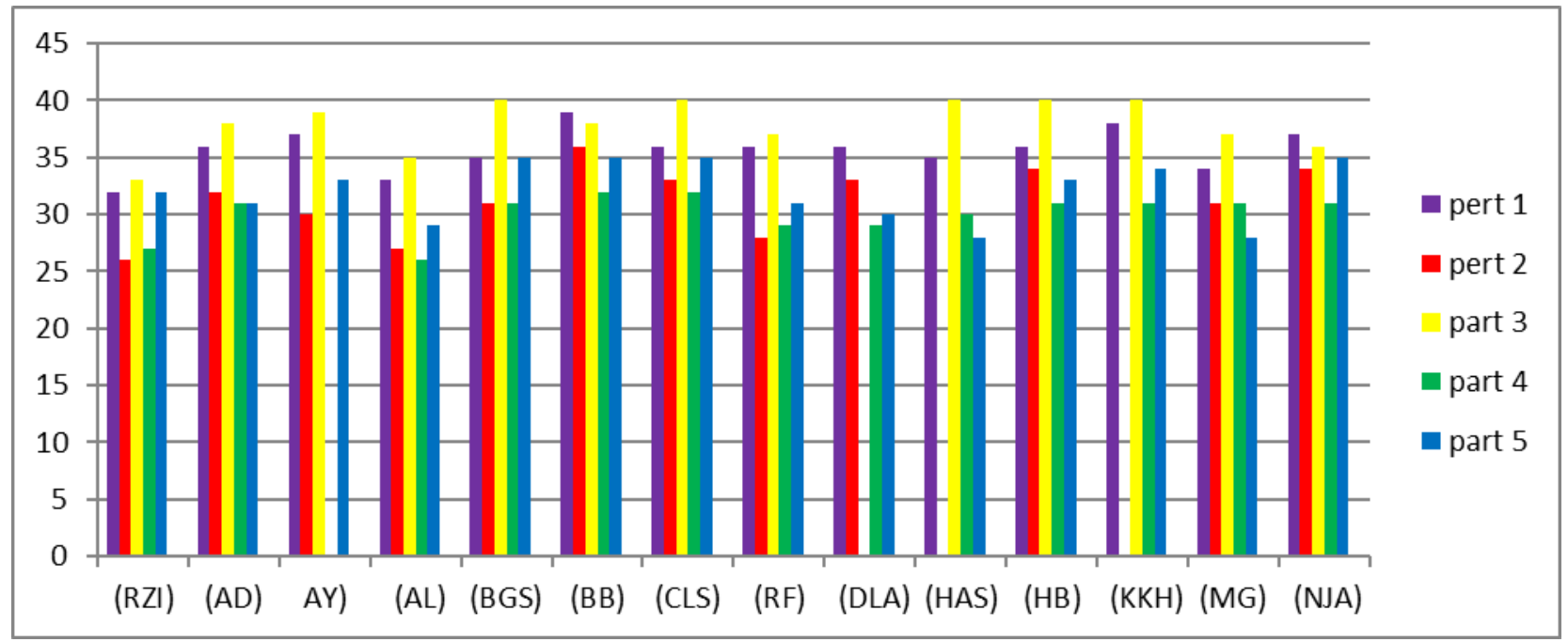

Gambar 3. Diagram Hasil Pengamatan Siklus II 
Ketiga siklus tersebut menggambarkan bahwa terjadi peningkatan secara signifikan dari setiap siklusnya baik pra siklus, siklus satu dan siklus dua. Berikut ini ditampilkan rekapitulasi pra siklus, siklus I dan siklus II

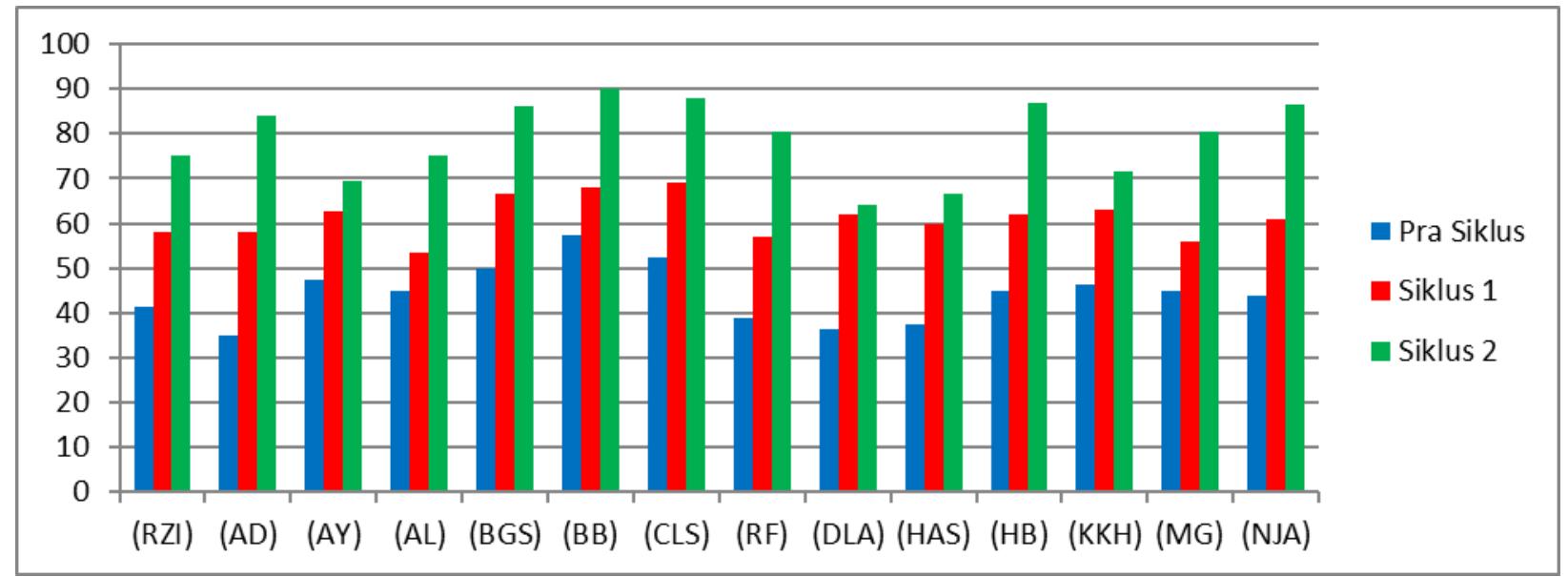

\section{Gambar 4. Diagram Perbandingan Hasil Rekapituasi Pengamatan}

Berdasarkan tabel rekapitulasi di atas maka nilai pra siklus sebesar 44,38\%. Artinya anakanak di kelas tersebut masih dalam kondisi rendah kemampuan kognitif khususnya dalam pembelajaran saisn. Pada siklus pertama dengan secara langsung menggunakan metode eksperimen pada pembelajaran sains untuk melihat perkembangan kognitifnya, maka diperoleh nilai sebesar $61,21 \%$. Hl ini terdapat peningkatan dari pra siklus sebesra $16.83 \%$. Artinya metode eksperimen memang dapat dilanjutkan pada siklus berikutnya. Peningkatan kemampuan kognitif dalam pembelajaran sains dengan menggunakan metode eksperimen pada siklus II diperoleh sebesar 78,86\%. Hal ini tentunya terlihat signifikansi sebuah metode kesperimen dapat meningkatkan kemampuan kognitif anak usia dini. Namun demikian hasil penelitian menunjukan masih ada beberapa anak yang belum mencapai kriteria indikator keberhasilan diantaranya AY mendapatkan 69,5\%, DLA mendapatkan 64\%, HAS mendapatkan 66,5\%, KKH mendapatkan 71,5\%. Walaupun 4 anak ini belum mencapai kriteria keberhasilan, setiap pertemuannya mengalami peningkatan yang signifikan. Faktor dukungan keluarga, lingkungan serta usia juga mempengaruhi keberhasilan 4 anak tersebut. 
Untuk mengetahui hasil dari pra siklus, siklus I dan siklus II, maka disajikan dalam tabel berikut:

Tabel rekapitulasi hasil pra siklus, siklus I, siklus II

\begin{tabular}{|c|c|c|c|c|}
\hline \multirow[t]{2}{*}{ No } & \multirow[t]{2}{*}{ Nama } & \multicolumn{3}{|c|}{ Prosentase } \\
\hline & & Pra Siklus & Siklus 1 & Siklus II \\
\hline 1 & (RZI) & 41.25 & 58 & 75 \\
\hline 2 & (AD) & 35 & 58 & 84 \\
\hline 3 & (AY) & 47.5 & 62.5 & 69.5 \\
\hline 4 & (AL) & 45 & 53.5 & 75 \\
\hline 5 & (BGS) & 50 & 66.5 & 86 \\
\hline 6 & (BB) & 57.5 & 68 & 90 \\
\hline 7 & (CLS) & 52.5 & 69 & 88 \\
\hline 8 & (RF) & 38.75 & 57 & 80.5 \\
\hline 9 & (DLA) & 36.25 & 62 & 64 \\
\hline 10 & (HAS) & 37.5 & 60 & 66.5 \\
\hline 11 & (HB) & 45 & 62 & 87 \\
\hline 12 & $(\mathrm{KKH})$ & 46.25 & 63 & 71.5 \\
\hline 13 & (MG) & 45 & 56 & 80.5 \\
\hline 14 & (NJA) & 43.75 & 61 & 86.5 \\
\hline & Jumlah & 621.25 & 856.5 & 1104 \\
\hline & Rata-rata & $44.38 \%$ & $61.18 \%$ & $78.86 \%$ \\
\hline
\end{tabular}

\section{SIMPULAN}

Penerapan metode eksperimen dalam pembelajaran sains untuk meningkatkan kemampuan kognitif anak usia dini di RA Baiturrahman memperoleh hasil yang baik. Pada awal penelitian, kemampuan kognitif dalam pembelajaran sains anak masih rendah. Hasil pra siklus menunjukan $44.38 \%$ artinya masih belum mampu. Kondisi ini berakibat pada terganggunya kemampuan dan pembelajaran sains anak seperti anak masih belum mengetahui tentang pencampuran wana, anak yang belum mampu mengenal benda dengan mengurutkan benda 
berdasarkan ukuran dari yang terpendek sampai yang terpanjang atau sebaliknya, dan anak jugabelum mampu mengungkapkan hasil karya yang dibuatnya secara lengkap.

Setelah dilakukannya penerapan metode eksperimen dalam pembelajaran sains untuk meningkatkan kemampuan kognitif anak usia dini yaitu dengan pengenalan warna, pencampuran warna, dan media yang mengenalkan anak tentang gejala alam. Dalam percobaan ini anak mulai berkembang dan meningkat dalam kemampuan kognitif dan pengetahuan sainsnya dibandingkan dengan sebelumnya, percobaan eksperimen ini juga menggunakan media yang berbeda dari yangpernah guru ajarkan kepada anak.

Penerapan metode eksperimen dalam pembelajaran sains untuk meningkatkan kemampuan kognitif anak usia dini pada kelompok B di RA Baiturrahman peningkatan kemampuan kognitif dalam pembelajaran sains pada siklus I mendapatkan $61,21 \%$, meningkat dari pra siklus sebesar $16.83 \%$. Kemudian meningkat kemampuan kognitif dalam pembelajaran sains pada siklus II sebesar 78,86\%. Hal ini menunjukan bahwa metode eksperimen sangat direkomendasikan untuk digunakan khususnya pada pembelajarn sains untuk meningkatkan kemampuan kognitif anak.

\section{DAFTAR PUSTAKA}

Ali, Nugraha. (2005). Pengembangan Pembelajaran Sains pada Anak Usia Dini. Jakarta: Departemen Pendidikan Nasional.

Arikunto, Suharismi. (2007), Penelitian Tindakan Kelas, Bandung: Bumi Aksara

Arikunto, Suharsimi, Suhardjono, \& Supardi. (2007). Penelitian Tindakan Kelas. Jakarta: Rineka Cipta.

Asrori, M. (2009).Penelitian Tindakan Kelas. Bandung: PT CV Wacana Prima.

Desmita. (2011). Psikologi Perkembangan. Bandung: PT Remaja Rosdakarya.

Djaali. (2014). Psikologi Pendidikan. Jakarta: PT Bumi Aksara.

Djamarah, Syaiful Bahri. (2014). Guru dan Anak Didik dalam Interaksi Edukatif. Jakarta: Renika Cipta.

Hamdayama, Jumanta. (2014). Model dan Metode Pembelajaran Kreatif dan Berkaraakter. Bogor: Ghalia Indonesia.

Penerapan Metode Eksperimen dalam
Pembelajaran Sains untuk Meningkatkan
Kemampuan Kognitif Anak Usia Dini

Kemampuan Kognitif Anak Usia Dini
Ery Khaeriyah, Aip Saripudin,

Riri KKartiyawati 
Kunandar. 2008. Langkah Mudah Penelitian Tindakan Kelas. Jakarta: Raja Grafindo Persada.

Latif, Mukhtar, dkk. (2013). Orientasi Baru Pendidikan Anak Usia Dini. Jakarta: Prenada Media Group.

Mutiah, Diana. (2015). Psikologi Bermain Anak Usia Dini. Jakarta: Prenada Media Group.

Moeslichatoen.(2004). Metode Pengajaran di Taman Kanak-Kanak. Jakarta: Rineka Cipta

Mulyasa.H.E (2012). Manajemen PAUD. Bandung. PT Remaja Rosdakarya

Mursid. (2015). Belajar dan Pembelajaran PAUD. Bandung. PT Remaja Rosdakarya.

Noor, Juliansyah, (2013). Metodologi Penelitian, Skripsi, Tesis, dan Karya Ilmiah. Jakarta: Prenada Media Grup.

Nurhayati, Eti. (2011). Psikologi Pendidikan Inovatif. Yogyakarta: Pustaka Pelajar.

Ormrod, Jeanne Ellis. (2008). Psikologi Pendidikan. Jakarta: Erlangga.

Rachmawati, Yeni, dkk. (2010). Strategi Pembelajaran Kreativitas pada Anak. Jakarta: Prenada Media Group.

Saifuddin.(2014). Pengelolaan Pembelajaran Teoretis dan Praktis.Yogyakarta: Deepublish.

Saripudin, A. (2016). Peran Keluarga dalam Mengoptimalkan Perkembangan Motorik Anak Usia Dini. AWLADY: Jurnal Pendidikan Anak, 2 (1).

Saripudin, A. (2017). Strategi Pengembangan Kecerdasan Naturalis Pada Anak Usia Dini. AWLADY: Jurnal Pendidikan Anak, 3 (1).

Saripudin, A., \& Faujiah, I. Y. (2018). Strategi Edutainment dalam Pembelajaran di PAUD (Studi Kasus Pada TK di Kota Cirebon). AWLADY: Jurnal Pendidikan Anak, 4 (1).

Santrock, John W. (2011). Masa Perkembangan Anak. Jakarta: Salemba Humanika.

Somadayo Samsu. (2013). Penelitian Tindakan Kelas. Yogyakarta: Graha Ilmu.

Sugiyono. (2014). Metode Penelitian Kuantittatif Kualitatif Dan R\&D. Bandung: Alfabeta.

Suminah, Enah, dkk. (2015). Penilaian Pembelajaran Pendidikan Anak Usia Dini. Jakarta: Direktorat Pembinaan Anak Usia Dini.

Susanto, Ahmad. (2011). Perkembangan Anak Usia Dini. Jakarta: Kencana.

Suyadi. (2014). Teori Pembelajaran Anak Usia Dini. Bandung: PT Remaja Rosdakarya

Suyadi \& Ulfah, M. (2013). Konsep Dasar PAUD. Bandung: PT Remaja Rosdakarya. Syah, Muhibbin. (2012). Psikologi Belajar. Jakarta: PT Raja Grafindo Persada.

$\begin{array}{lrr}\text { Penerapan } & \text { Metode } & \text { Eksperimen dalam } \\ \text { Pembelajaran Sains untuk Meningkatkan } & \text { Ery Khaeriyah, Aip Saripudin, } \\ \text { Kemampuan Kognitif Anak Usia Dini } & \text { Riri KKartiyawati }\end{array}$


Email : pgrasyekhnurjati@gmail.com

P-ISSN: 2541-4658

Ulfah ,M. (2014). Pengembangan Pembelajaran Aktif, Inovatif, Kreatif, Efektif Dan Menyenangkan (Paikem) Di Sekolah Taman Kanak-Kanak Fullday. Pawiyatan.

Yulianti, Dwi. 2010. Bermain Sambil Belajar Sains di Taman Kanak-Kanak. Jakarta: Indeks. 